УДК [620.952:338.984]

DOI https://doi.org/10.15673/swonaft.v84i1.1875

\title{
МЕТОДИ ПРОГНОЗУВАННЯ ЯКОСТІ ТВЕРДОГО ПАЛИВА
}

\author{
Бунецький В. О. ${ }^{1}$, експерт у галузі біоенергетики та пелетного виробництва, керівник \\ інжинірингової компанії у галузі переробляння біомаси ООО ВМ-Engineering, acпірант, \\ Корінчук Д. М. ${ }^{2}$, канд. тех. наук \\ ${ }^{1}$ Харківський національний технічний університет сільського господарства ім. Петра Василенка \\ ${ }^{2}$ Інститут технічної теплофізики НАН України
}

\begin{abstract}
Анотація. У статті, на базі запропонованих авторами методів наукового передбачення якісних показників твердого біопалива, запропоновано інновачійні методи прогнозування (розраховування) якісних характеристик вироблюваного твердого біопалива (пелет, брикетів). 3 огляду на те, щуо деревина, яка є сировиною для виробляння твердого біопалива, є біополімером, готова продукція, вироблена з неї, також буде композиційним біополімером.

У статті обтрунтовано очевидну залежність якості готової продукиї (пелет, брикетів) від вологості початкової деревини та ї̈ породи. Крім того, було взято до уваги умови та термін зберігання заготовленої сировини, щуо впливають на вологість, наявність грибків та бактерій, а також хімічний склад деревини з урахуванням ї̈ породи. Всі иі показники також значною мірою впливають на якість готової продукиії. При изьому хімічний склад біополімерів різних порід на порядки відрізняється за вмістом важких металів та сірки, які потім впливають на зольність та екологічні показники біопалива та на їх відповідність європейським стандартам ENPlus.

За результатами детального аналізування фізико-хімічних та реологічних властивостей біополімерів, вперше було запропоновано точний метод розрахунку теплотворної здатності, зольності та міцності вироблюваного твердого біопалива (композитного біополімера).

Діаграми та дані щьодо фактичного складу деревини різних порід та формули для розраховування фізико-хімічних та реологічних властивостей готової продукиї, слугують основою для подальшого прогнозування ї̈ якості, та ї̈ гарантованого сертифікування за європейськими стандартами ENPlus.

Обтрунтовані переваги біопалива другого покоління (поверхневозасклованих пелет) та третього покоління (плавленого біовугілля).

Нажаль, натепер виробники твердого біопалива не прогнозують його якість, а лише після отримання готової продукиії не систематично контролюють ї̈ на відповідність європейським або вітчизняним стандартам. Новизна запропонованих методів прогнозування якості твердого біопалива ще на стадії контролю первинної сировини є важливою основою для створення сучасних технологій та обладнання, які будуть реалізовувати енергоефективне та окупне виробляння твердого біопалива.

Ключові слова: біопаливо, біомаса, біополімер, склад сировини, породи деревини, пелети, поверхнево заскловані пелети, плавлене біовугілля, фізико-хімічні властивості, реологічні властивості.
\end{abstract}

\section{SOLID BIOFUEL QUALITY FORECASTING METHODS}

\author{
Buneckiy V.O. ${ }^{1}$, expert in bioenergetics and pellet's production field, engineering company in biomass \\ processing head Ltd BM-Engineering, graduate student, \\ Korinchuk D.M. ${ }^{2}$, PhD \\ ${ }^{1}$ Kharkiv Petro Vasylenko National Technical University of Agriculture \\ ${ }^{2}$ Institute of Engineering Thermophysics of NAS of Ukraine
}

\begin{abstract}
In the article, on the basis of introduced by authors methods for scientific prediction of solid biofuel qualitative indicators where offered innovative forecasting (calculation) methods for produced solid biofuel (pellets, briquettes) qualitative characteristics. On this account that wood, which is the raw material for solid biofuel production is a biopolymer, the finished product made from it will also be a composite biopolymer.
\end{abstract}


Одеська національна академія харчових технологій

\section{ЕНЕРГОЕФЕКТИВНІСТЬ. РЕСУРСОЗБЕРІГАЮЧІ ТА ЕКОЛОГІЧНО-БЕЗПЕЧНІ} ЕНЕРГОТЕХНОЛОГІї

The article substantiates the obvious dependence of the finished products (pellets, briquettes) quality on the moisture content of the original wood and its race. In addition, the conditions and shelf life of harvested raw materials, which affect on humidity, the presence of fungi and bacteria, as well as the chemical composition of wood, taking into account its race, were taken into account. All these indicators also significantly affect on the quality of finished products. Under such conditions the chemical composition of biopolymers of different races differs by orders of magnitude in the content of heavy metals and sulfur, which then affect on the ash content and ecological dimensions of biofuels and their compliance with European standards ENPlus.

Based on the physicochemical and rheological biopolymers properties detailed analysis results, for the first time an accurate method for calculating the calorific value, ash content and strength of the produced solid biofuel (composite biopolymer) was proposed.

Diagrams and data on the actual composition of wood of different races and formulas for calculating of the finished products physicochemical and rheological properties, serve as a basis for further forecasting of its quality and its guaranteed certification according to European standards ENPlus.

The second generation biofuel (surface glazed pellets) and the third generation (fused biochar) advantages where grounded.

Unfortunately, at present, solid biofuels producers do not forecast its quality, and only after finished product receiving do not systematically control it for compliance with European or domestic standards. The novelty of the proposed methods for solid biofuels quality forecasting at the primary raw materials control stage is an important basis for the creation of modern technologies and equipment that will implement energy-efficient and cost-effective solid biofuels production.

Key words: biofuel, biomass, biopolymer, raw materials composition, wood race, pellets, surface vitrificated pellets, fused biochar, physicochemical properties, rheological properties.

Вступ. У наш час у всьому світі значну увагу приділяють підвищенню теплотворної здатності твердого біопалива. Цю статтю присвячено екологічній складовій галузі теплоенергетики та ії енергоефективності, а саме приведенню якості біопалива до міжнародних стандартів якості. Поступова заміна викопного палива на екологічно чисте відновлюване, підвищує вимоги комунальної енергетики та окремих споживачів до якості, екологічності та енергоємності пелет та брикетів.

Важливість та актуальність використання твердого біопалива також базуються на тому, що воно є поновлюваним джерелом енергії та не залежить від поступового виснаження природних ресурсів. Тому прогнозування його якості є таким важливим для виробників. У цій статті запропоновані сучасні точні методи прогнозування якості вироблюваного палива у залежності від використовуваної сировини та технологічного процесу виробництва.

У світі постійно зростає частка використання біопалива у вироблянні теплової та електричної енергії. Викопне паливо дорожчає, також зростають штрафи за його використання. Тому у Директиві EC 2012/27EU щодо енергоефективності [1], та у Висновках Європейської Ради від 8 и 9 березня 2007 р. було вказано на необхідність підвищення енергоефективності у країнах СС задля економії у порівнянню із прогнозами до кінця 2020 року на 20 \% від обсягу первинного енергоспоживання у СС.

Очевидно, що для України, яка володіє великими, постійно поновлюваними запасами біомаси різного походження, ефективне виробляння високоякісного сертифікованого біопалива за стандартами якості ENPlus може стати основою для формування однієї із самих прибуткових та наукоємних галузей енергетики [2].

Мета роботи - обгрунтування методів прогнозування якості вироблюваного твердого біопалива на базі розраховування його властивостей з урахуванням характеристик деревної сировини, як біополімеру.

Об'єктом дослідження є метод розраховування характеристик твердого біопалива за параметрами вихідної сировини.

Предмет дослідження - деревна сировина, як біополімер, та тверде біопаливо як композитний біополімep.

Усі дослідження було виконано на базі компанії ООО ВМ-Engineering.

Аналіз проблематики та останні дослідження. Цю статтю присвячено обгрунтуванню використання методів розрахунку та прогнозування якості біопалива чотирьох поколінь. Без науково обгрунтованого прогнозування якості біопалива неможливо створити ефективне виробництво та забезпечити гарантований збут якісної продукції [3]. Ці методи повинні базуватися на експериментальному визначенні точних фізикохімічних та реологічних характеристик біомаси, як композиційного біополімеру. Важливим фактором, який принципово впливає на фізико-хімічні перетворення біомаси у процесі їі пресування, є характер деформаційного впливу на її волокна. 


\section{Одеська національна академія харчових технологій ЕНЕРГОЕФЕКТИВНІСТЬ. РЕСУРСОЗБЕРІГАЮЧІ ТА ЕКОЛОГІЧНО-БЕЗПЕЧНІ ЕНЕРГОТЕХНОЛОГІї}

Для біополімерів у будь-якому релаксаційному стані характерно співіснування усіх трьох видів деформації - пружної, високоеластичної та в'язкої - з переважанням одного з них. Релаксаційний характер процесів деформації полімерів призводить до того, що межі між релаксаційними станами визначають не лише за температурою та структурними характеристиками речовини, а й за типом навантаження (значенням, швидкістю і тривалістю навантаження).

Залежно від характеру навантаження, один і той же біополімер при заданій температурі та структурних характеристиках може вести себе як пружне, високо еластичне, або пластичне тіло. Під час впливу на полімер «швидких» сил (ударного навантаження) - головним чином проявляється пружність, а у разі впливу «повільних» сил - в основному пластичність.

Біополімер, що є при заданій температурі і структурних характеристиках високоеластичним, при великій швидкості короткочасних навантажень поводить себе як пружне тіло, а при тривало діючій силі виявляє плинність, а рідкий полімер може за певних умов проявити високоеластичнисть, та навіть пружність. для отримання максимально щільної гранули за найменших енергетичних витрат. Тому у процесі пресування біомаси необхідно створити умови для максимального прояву механізму деформації в'язкої течії.

Переважання властивостей пластичності при пресуванні повинно призводити до змін в надмолекулярної структурі біополімеру в напрямі збільшення щільності упаковки молекул, а значить, отримання гранул високої щільності. Іншими словами, навантаження при пресуванні підготовленої біомаси повинно бути максимально «повільним».

Окремо слід відзначити впив деформацій зсуву на енерговитрати стадій подрібнення та пресування. Як відомо, саме опір деформаціям зсуву у двічі менший, за деформацію осьового стискання чи розтягування. Урахування реологічних властивостей біомаси при залученні деформацій зсуву вологих шарів біополімерів необхідне під час підготування (подрібнювання та пресування) початкової сировини. Контролю якості сировини повинні приділяти увагу на усіх підприємствах, які поставили собі за мету виробляти якісну продукцію [4].

Окрім високих екологічних характеристик, одним із визначальних показників, від яких залежить якість та вартість пелет (брикетів), є їх теплотворна спроможність, адже паливо призначене саме для виробляння енергії. Як відомо з теплофізики, вища теплотворна спроможність (Higher Calorific Value = Gross Calorific Value $=\mathrm{GCV}=\mathbf{B T C}$ ) - кількість теплоти, що виділяється при повному згорянні палива, охолодженні продуктів згоряння до початкової температури палива та конденсації водяної пари, що утворилася при окисленні водню, що входить до хімічного складу палива. Нижча теплотворна здатність (Lower Calorific Value = Net Calorific Value $=$ NCV $=$ HTC) - кількість теплоти, що виділяється при повному згорянні палива без конденсації водяної пари.

Основні проблеми, з якими стикаються виробники твердого біопалива - високі питомі енерговитрати на виробляння однієї тонни готової продукції, и як наслідок - довготривалий період окупності встановленого обладнання.

Усі ці проблеми обумовлені використанням неефективних технологій, подрібненням сухої сировини, великою кількістю відходів, и як наслідок, підвищеними енерговитратами. Тому обрання правильної наукосмної інноваційної технології для виробляння пелет повинно охоплювати усі етапи виробничого циклу зберігання, підготування и подрібнення сировини, пресування готової продукції. Особливо важливим є саме використання технологій: зсувних деформацій біополимерів під час підготування сировини, зволоженого пресування та виробляння пелет другого і третього поколінь [5].

Результати досліджень та їх обговорення. Прогнозована вартість та якість готової продукції напряму залежать від якості початкової сировини. Величину нижчої та вищої теплоти згоряння треба визначати на одиницю сухого палива (як правило, на один кг або на один м³) або на одиницю палива з урахуванням його вологості.

Окрім вологи, що входить до складу готового палива, необхідно брати до уваги та ураховувати те, що волога також утворюється під час згоряння водню при хімічному сполученні його з атмосферним киснем. Під час визначення значення ВТС припускають, що волога конденсується у воду, а при вираховуванні значення НТС припускають, що волога вже знаходиться у складі палива у вигляді насиченої пари. Найбільш часто теплотворну спроможність вимірюють у Дж/кг (Дж/м $\left.{ }^{3}\right)$, МДж/кг (МДж/м³). Значення ВТС для пелет зазвичай складає 17 - 21 МДж/кг.

Теплоту згоряння визначає хімічний склад горючої речовини та вона залежить від наявності:

- горючих складових палива (вуглецю, водню, летючої горючої сірки та ін.);

- вологості та зольності палива.

Чим вищою буде питома теплота згоряння палива, тим менше його витрати для виробляння тієї ж кількості теплової енергії. Тому саме теплотворна здатність є однією з найбільш важливих характеристик палива. 
Під час виробляння пелет (брикетів) великий вплив на собівартість технологічного процесу чинять якість та вологість сировини. На рис. 1 показано, як треба визначати вологість сировини (наприклад, деревного палива) та відмінність аналогічних розрахунків під час визначення вологості деревини у якості пиломатеріалу.

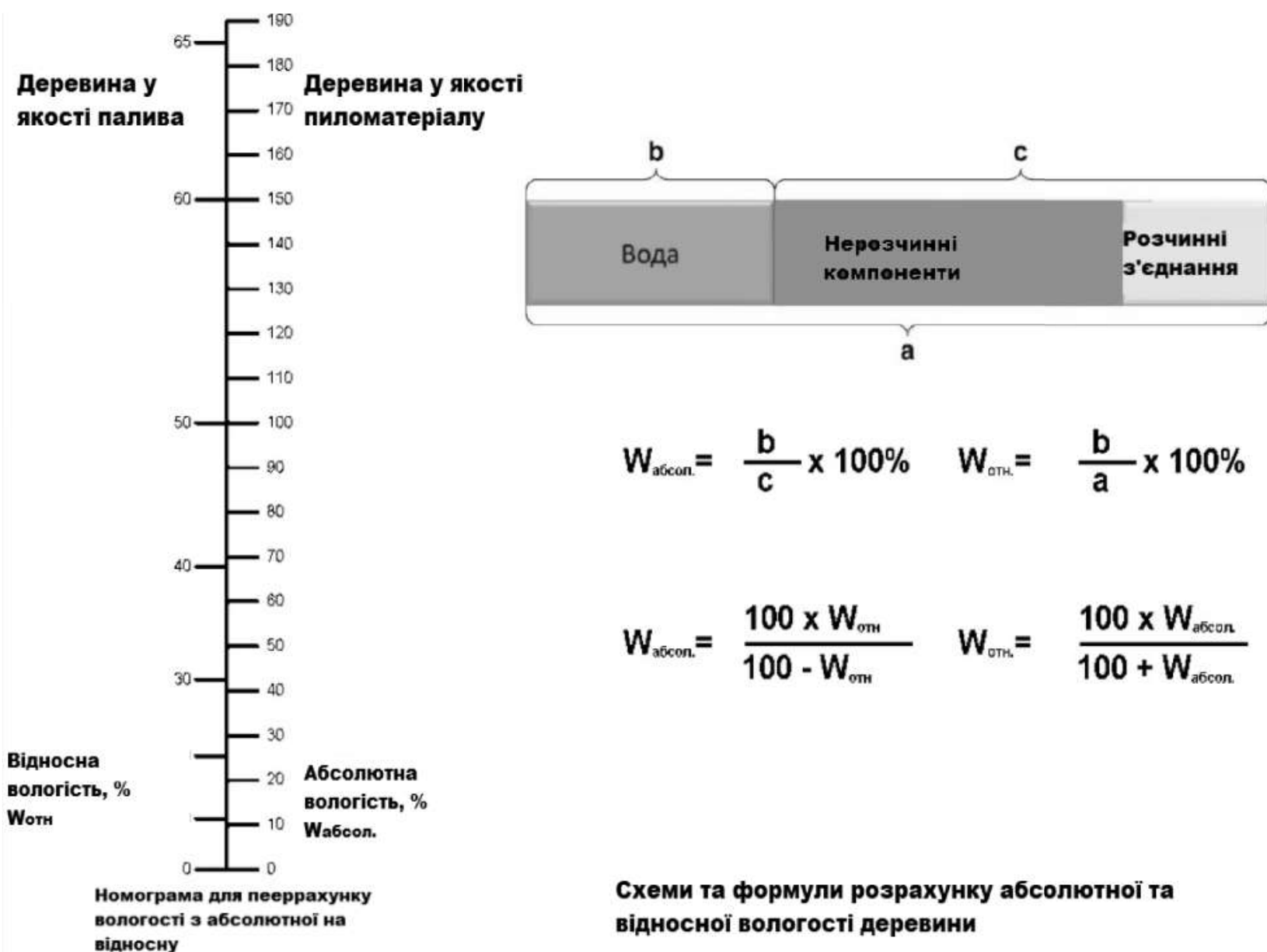

Рис. 1 - Номограма для перерахування вологості, схема та формули для розрахунку

Відносна вологість деревини $\mathbf{W}_{\text {отн }}$ - відношення маси вологи, яку утримує деревина, до маси деревини у вологому стані.

Абсолютна вологість $\mathbf{W}_{\text {абсол }}$ відношення маси вологи, що знаходиться у цьому обсязі деревини, до маси абсолютно сухої деревини того ж обсягу.

Вологість свіжої деревини, зазвичай, становить 40 - 60\%, та залежить від багатьох факторів, у тому числі місця вирощування, виду дерева, пори року (під час росту влітку вологість вища, взимку - нижча). Вологість окремих частин дерева також різна.

Вологість рослинної біомаси також залежить від сезону. Під час збирання зернових культур вологість рослинної біомаси становить 30 - 60\%. Оскільки при зберіганні вологість знижується на 2 - 6\%, то для одержання придатної до спалювання рослинної біомаси ії треба використовувати при вологості 20 - 25\%.

Більш вологу біомасу треба підсушити до складування, або на складі. Це захистить ії від самонагрівання та гниття під час зберігання. Теплотворна спроможність деревини напряму залежить від їі щільності, сорту та виду деревних порід (хімічного складу і структури), та може змінюватися у дуже широких межах. Відомо, що щільність деревини нестабільна. Вона залежить від породи деревини, рівня вологості, та навіть в одній і тій самій породі може бути різною.

Залежність теплоти згоряння від абсолютної вологості деревини (усереднена для різних порід деревини) показана на рис. 2. 


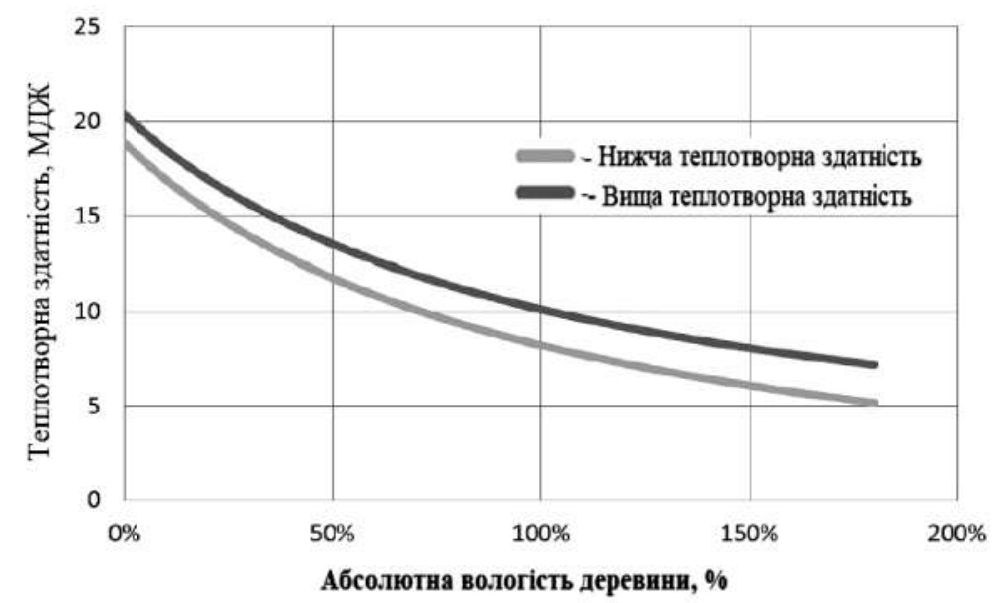

Рис. 2 - Залежність НТС и ВТС від абсолютної вологості деревини

Експериментально визначені середні довідкові відомості (Табл. 1) щодо теплотворної спроможності дров, які мають різний вміст вологи у своєму складі. Наприклад, прийнято вважати, що:

- $12 \%$ - це добре висушені дрова в умовах їх зберігання в ізольованих приміщеннях (кімнатах, кухнях, котельних);

- $\quad$ 25\% - дрова, що були висушені на зовнішньому повітрі під дахом (навіси, сараї, склади);

- $\quad$ 50\% - сирі дрова зі свіжозрубаної деревини.

Залежність теплотворної спроможності дров від породи деревини та її вологості

Таблиця 1

\begin{tabular}{|l|c|c|c|c|c|c|}
\hline \multirow{2}{*}{ Порода } & \multicolumn{3}{|c|}{$\begin{array}{c}\text { Теплотворна спроможність, } \\
\text { ккал/дм }{ }^{3}, \text { за вологості, \% }\end{array}$} & \multicolumn{3}{|c|}{$\begin{array}{c}\text { Теплотворна спроможність, } \\
\text { кВт·г/. }{ }^{3}, \text { при вологості, \% }\end{array}$} \\
\cline { 2 - 8 } & $12 \%$ & $25 \%$ & $50 \%$ & $12 \%$ & $25 \%$ & $50 \%$ \\
\hline \multirow{2}{*}{ Дуб } & 3240 & 2527 & 1110 & 3758 & 2932 & 1287 \\
\hline Модрина & 2640 & 2059 & 904 & 3062 & 2389 & 1049 \\
\hline Береза & 2600 & 2028 & 891 & 3016 & 2352 & 1033 \\
\hline Кедр & 2280 & 1778 & 781 & 2645 & 2063 & 906 \\
\hline Сосна & 2080 & 1622 & 712 & 2413 & 1882 & 826 \\
\hline Осика & 1880 & 1466 & 644 & 2181 & 1701 & 747 \\
\hline Ялина & 1800 & 1404 & 617 & 2088 & 1629 & 715 \\
\hline Ялиця & 1640 & 1279 & 562 & 1902 & 1484 & 652 \\
\hline Тополя & 1600 & 1248 & 548 & 1856 & 1448 & 636 \\
\hline
\end{tabular}

В елементному складі деревного палива переважають три хімічні компоненти: вуглець $(\mathrm{C})$, водень $(\mathrm{H})$ та кисень (O), що утворюють у сумі близько 99 \% від сухої маси. Вміст азоту (N) залишається зазвичай нижче $0,2 \%$, сірки $(\mathrm{S})$ - нижче $0,05 \%$ від сухої маси. Вміст сірки у паливі становить інтерес насамперед через виникнення сірчистих відходів, однак, при ії високому вмісті може виникати загроза низькотемпературної корозії у газоходах та димарі. Оскільки хлор $(\mathrm{Cl})$ також може викликати корозію поверхонь нагрівання, важливо знати і його вміст у паливі. Хлор може створювати проблему при спалюванні, наприклад, тріски хвойних порід, якщо їх частка в паливі досить велика.

Хоча вміст важких металів у деревній масі не сягає небезпечних величин, у випадку жорстких вимог до охорони довкілля на них слід уважатися. У різних частинах дерева містяться у малих кількостях нікель, арсен, кадмій, хром, мідь, ртуть, свинець та цинк.

Поряд 3 деревним паливом використовують паливо рослинного походження, у тому числі енергетичні сіно та солому. Властивості біомаси рослин значною мірою залежать від місця вирощування, пори року i погоди, грунту і добрив. Наприклад, вміст хлору у рано прибраній соломі майже у 4 рази вище, ніж у пізній. Максимальний вміст хлору може досягати 0,97 \%, і це впливає на корозію поверхонь нагрівання при спалюванні.

Типові значення показників, які характеризують властивості природних деревних матеріалів без кори, листя та хвої, або з незначною їх кількістю у відповідності до ISO 17225-1:2014 наведено у табл. 2. Саме 3 використанням цих показників вираховують фізико-хімічні характеристики вироблюваного біопалива.

Наукові праці, Том 84, випуск 1

Scientific Works, Volume 84, Issue 1 
Одеська національна академія харчових технологій

Типові значення показників складу хімічних речовин у деревних матеріалах без кори, листя та хвої, або із незначною їх кількістю

\begin{tabular}{|c|c|c|c|c|c|}
\hline \multirow[b]{2}{*}{ Назва показника } & \multirow{2}{*}{$\begin{array}{c}\text { Одиниця } \\
\text { вимірювання }\end{array}$} & \multicolumn{2}{|c|}{ Хвойна деревина } & \multicolumn{2}{|c|}{ Листяна деревина } \\
\hline & & \begin{tabular}{|c} 
Tипове значен- \\
ня \\
\end{tabular} & $\begin{array}{c}\text { Tиповий діапа- } \\
\text { зон значень }\end{array}$ & Типове значення & $\begin{array}{c}\text { Типовий діапа- } \\
\text { зон значень }\end{array}$ \\
\hline Зольність & $\%$ & 0,3 & $0,1-1,0$ & 0,3 & $0,2-1,0$ \\
\hline Вища теплота згоряння & МДж/кг & 20,5 & $20,0-20,8$ & 20,1 & $19,4-20,4$ \\
\hline Нижча теплота згоряння & МДж/кг & 19,1 & $18,5-19,8$ & 18,9 & $18,4-19,2$ \\
\hline Вуглець, С & $\%$ & 51 & $47-54$ & 49 & $48-52$ \\
\hline Водень, Н & $\%$ & 6,3 & $5,6-7,0$ & 6,2 & $5,9-6,5$ \\
\hline Кисень, О & $\%$ & 42 & $40-44$ & 44 & $41-45$ \\
\hline Азот, N & $\%$ & 0,1 & $<0,1-0,5$ & 0,1 & $<0,1-0,5$ \\
\hline Сірка, S & $\%$ & $<0,02$ & $<0,01-0,02$ & 0,02 & $<0,01-0,05$ \\
\hline Хлор, СI & $\%$ & 0,01 & $<0,01-0,03$ & 0,01 & $<0,01-0,03$ \\
\hline Фтор, F & $\%$ & $<0,0005$ & $<0,0005$ & $<0,0005$ & $<0,0005$ \\
\hline Алюміній, Al & МГ/Кг & 100 & $30-400$ & 20 & $<10-50$ \\
\hline Кальцій, Са & МГ/Кг & 900 & $500-1000$ & 1200 & $800-20000$ \\
\hline Залізо, Fe & МГ/КГ & 25 & $10-100$ & 25 & $10-100$ \\
\hline Калій, K & МГ/Кг & 400 & $200-500$ & 800 & $500-1500$ \\
\hline Магній, Mg & МГ/КГ & 150 & $100-200$ & 200 & $100-400$ \\
\hline Марганець, Mn & МГ/Кг & 100 & $40-200$ & 83 & - \\
\hline Натрій, $\mathrm{Na}$ & МГ/КГ & 20 & $10-50$ & 50 & $10-200$ \\
\hline Фосфор, P & МГ/Кг & 60 & $50-100$ & 100 & $50-200$ \\
\hline Кремній, Si & МГ/КГ & 150 & $100-200$ & 150 & $100-200$ \\
\hline Титан, Ті & МГ/Кг & $<20$ & $<20$ & $<20$ & $<20$ \\
\hline Арсен, As & МГ/Кг & $<0,1$ & $<0,1-1,0$ & $<0,1$ & $<0,1-1,0$ \\
\hline Кадмій, Cd & $\mathrm{M} \Gamma / \mathrm{К} Г$ & 0,10 & $<0,05-0,50$ & 0,10 & $<0,05-0,50$ \\
\hline $\mathrm{Xpoм,} \mathrm{Cr}$ & МГ/Кг & 1,0 & $0,2-10,0$ & 1,0 & $0,2-10,0$ \\
\hline Мідь, $\mathrm{Cu}$ & МГ/Кг & 2,0 & $0,5-10,0$ & 2,0 & $0,5-10,0$ \\
\hline Ртуть, $\mathrm{Hg}$ & $\mathrm{M} \Gamma / \mathrm{\kappa} \Gamma$ & 0,02 & $<0,02-0,05$ & 0,02 & $<0,02-0,05$ \\
\hline Нікель, Ni & МГ/кГ & 0,5 & $<0,1-10,0$ & 0,5 & $<0,1-10,0$ \\
\hline Свинець, $\mathrm{Pb}$ & МГ/Кг & 2,0 & $<0,5-10,0$ & 2,0 & $<0,5-10,0$ \\
\hline Ванадій, V & мг/кГ & $<2$ & $<2$ & $<2$ & $<2$ \\
\hline Цинк, Zn & МГ/Кг & 10 & $5-50$ & 10 & $5-100$ \\
\hline
\end{tabular}

Відомі дані щодо хімічного складу деревної сировини дозволяють спрогнозувати (розрахувати) приблизне значення теплотворної спроможності кінцевої продукції - пелет (брикетів). 3 урахуванням того, що теплову енергію отримують від згоряння сухої беззольної маси, можна вважати, що теплотворна спроможність значною мірою залежить від рівня вологості, з огляду на те, що випаровування води також потребує додаткових витрат енергії. Таким чином, розрахункову ВТС пелет (брикетів) можна досить точно визначити за формулою, яку отримано емпіричним шляхом, за результатами проведених дослідів:

$\mathbf{B T C}=0,3491 * \mathbf{C}+1,1783 * \mathbf{H}+0,1005 * \mathbf{S}-0,0151 * \mathbf{N}-0,1034 * \mathbf{O}-0,0211 * \mathbf{A}$, МДж/кг де,

С - вміст у складі пелет вуглецю (C);

Н - вміст у складі пелет водню $(\mathrm{H})$;

$\mathrm{S}$ - вміст у складі пелет сірки (S);

$\mathrm{N}$ - вміст у складі пелет азоту $(\mathrm{N})$;

О - вміст у складі пелет кисню (O);

А - вміст у складі пелет золи у вагових \%.

Як слідує з цієї формули, збільшення вмісту вуглецю та водню підвищує ВТС, а збільшення вмісту азоту, кисню та золи знижує ВТС. Необхідно відзначити, що у середньому значення розрахункової теплотворної спроможності на 1,8 \% нижче за виміряне значення ВТС. Природно, що пелети (брикети) із більш високою теплотворною спроможністю, мають більш привабливі споживчі якості, та їх легше продавати. Виробник може впливати на вміст указаних вище хімічних елементів у пелетах (брикетах) шляхом цілеспрямованого вибору сировини, його підготування та зменшення втрат сировини під час виробляння продукції на конкретному підприємстві. Наприклад, вміст золи зазвичай складає декілька відсотків, або долі відсотка (0,3 \% у деревині ялини або берези без кори, 1,6 \% у березовій корі та 3,4 \% у корі ялини). Різні породи дерев відрізняються вмістом азоту, яке складає у середньому 0,75 \%. Наприклад, тріска, яку було отримано 3 так 


\section{Одеська національна академія харчових технологій ЕНЕРГОЕФЕКТИВНІСТЬ. РЕСУРСОЗБЕРІГАЮЧІ ТА ЕКОЛОГІЧНО-БЕЗПЕЧНІ ЕНЕРГОТЕХНОЛОГІї}

званої азотфіксуючої деревини таких дерев, як вільха, містить більш ніж у два рази більше азоту, ніж тріска, яку було отримано 3 деревини хвойних порід. 3 огляду на те, що плавкісні характеристики золи біопалив безпосередньо впливають на роботу котла, необхідно під час виробляння пелет та брикетів значну увагу приділяти саме цим характеристикам. Плавлення золи може викликати шлакування топки та виникнення щільних відкладань на конвективних поверхнях нагрівання, що особливо актуально в умовах України, при переведенні котельного обладнання на використання альтернативних палив.

Для визначення плавкісних характеристик золи існує ряд стандартів: американський ASTM D1857 та європейські ISO 540 та DIN 51730. За стандартом ASTM вимірюють зміну форми стандартного конуса золи при його нагріванні в окисному середовищі (рис. 3).

Плавкісні характеристики деревної золи можуть коливатися у широких межах залежно від виду дерева, місця зростання, включень, що потрапили у паливо (наприклад із грунту). Відрізняється й зола різних частин дерева. 3 літературних джерел відомо, що плавкісні характеристики деревної золи достатньо високі.

Якщо у золи кори температура розм'якшення вище $1500^{\circ} \mathrm{C}$ та вона не викликає шлакування топки й колосника, то для золи ошурок і тріски вона нижче, і для того, щоб уникнути проблем шлакування необхідно строго витримувати режим горіння. Температура плавлення золи рослинної біомаси може бути значно нижчою, ніж у золи деревних палив, розм'якшення золи соломи жита, вівса та ячменя починається при дуже низьких температурах (735$840^{\circ} \mathrm{C}$ ), що необхідно враховувати при виборі технології спалювання й налагодженні режиму горіння у топці.

Висновки. Енергоефективну технологію виробляння пелет (брикетів) необхідно базувати на науково обгрунтованих методах прогнозування (розрахування) якості біопа-

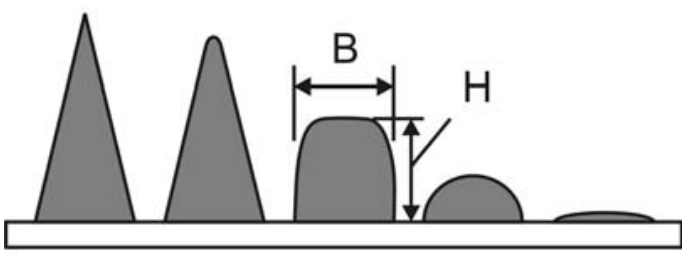

$1 \quad$ IT $\quad$ ST $\quad$ HT $\quad$ FT 1 - вихідний стан, до початку нагрівання (верхівка конуса гостра); IT - початок деформачї, гостра вершина конуса округлюється; ST - точка розм'якшення, золовий конус сплюшується так, щзо величина твірних зменшується до діаметру $(H=B)$; HT - точка утворення напівсфери, конус перетворюється у напівсферу $(H=0,5 \cdot B)$; FT - точка розтікання, рідка зола розтікається по поверхні

\section{Рис. 3 - Зміна форми стандартного ко- нуса золи при його нагріванні} лива, яке виробляють із біополімерів різного походження. Запропоновані автором методи базуються на:

1. аналізуванні та контролюванні хімічного складу, фізичних та реологічних властивостях сировинної бази, іiі характеристиках, логістиці постачання сировини та умовах її зберігання, які значною мірою впливають на вологість та склад сировини;

2. необхідності проведення сертифікації використовуваної сировини, що дасть можливість сертифікувати вироблене паливо за стандартами EN Plus;

3. прогнозуванні якості сировини, що дасть можливість обгрунтувати вибір технології виробництва біопалива з урахуванням прав інтелектуальної власності на розроблені інноваційні технології для виробляння пелет другого та третього поколінь.

Вперше запропоноване автором використання інформації щодо прогнозування властивостей та якості вироблюваного твердого палива дасть можливість попередньо оцінити технічні, екологічні та економічні параметри проекту створення пелетного виробництва, визначити та обгрунтувати термін його окупності та створить прогноз прибутковості.

\section{References}

1. Directive 2012/27/EU of the European Parliament and of the Council of 25 October 2012 on energy efficiency, amending Directives 2009/125/EC and 2010/30/EU and repealing Directives 2004/8/EC and 2006/32/EC. Brussels, Belgium: European Council. (2012).

2. Pro Natsional'nyy plan diy z vidnovlyuvanoyi enerhetyky na period do 2020 roku. № 902-r. (2014).

3. Lugovaya, D., (2013). Printsipi ustoychivogo proizvodstva drevesnogo biotopliva. Les I Klimat, Ustoychivoye Lesopol'zovaniye, 4 (37), 36-42

4. Berthold Otzisk, Kurita Europe, Quality control in biofuels production, Retrieved from https://www.digitalrefining.com/article/1001002/quality-control-in-biofuels-production\#.X8OtYmgza70

5. Voytov, V.A., Kravtsova, N.V., Bunetskiy, V.A. (2012). Vlazhnoye pressovaniye - odin iz putey snizheniya energozatrat pri proizvodstve tverdogo biotopliva iz biomassy. Khraneniye i pererabotka zerna, 11 (161), $48-$ 53.

Отримано в редакцію 15.07.2020

Received 15.07.2020

Прийнято до друку 05.11.2020

Approved 05.11.2020 